\title{
Rainer Eisfeld
}

\section{POLITICAL SCIENCE IN GREAT BRITAIN AND GERMANY: THE ROLES OF LSE (THE LONDON SCHOOL OF ECONOMICS) AND DHFP (THE GERMAN POLITICAL STUDIES INSTITUTE)}

DOI: $10.1515 /$ ppsr-2015-0022

\begin{abstract}
The London School of Economics and Political Science (LSE) and the Deutsche Hochschule für Politik (DHfP, German Political Studies Institute) in Berlin both emerged extramurally. LSE was founded in 1895 by Fabian socialists Sidney and Beatrice Webb; DHfP was established in 1920 by liberal-national publicists Ernst Jäckh and Theodor Heuss. However, superficial resemblances ended there, as shown in the paper's first part. The founders' aims differed markedly; incorporation into London and Berlin universities occurred at different times and in different ways.

The chair of political science set up at LSE in 1914 was held, until 1950, by two reform-minded Fabians, Graham Wallas and Harold Laski. DHfP, which did not win academic recognition during the 1920s, split into nationalist, "functionalist", and democratic "schools". Against this backdrop, the paper's second part discusses Harold Laski's magnum opus (1925) A Grammar of Politics as an attempt at offering a vision of the "good society", and Theodor Heuss' 1932 study Hitler's Course as an example of the divided Hochschule's inability to provide adequate analytical assessments of the Nazi movement and of the gradual infringement, by established elites, of the Weimar constitution. Laski's work and intellectual legacy reinforced the tendency towards the predominance, in British political science, of normative political theory. West German political science, initially pursued "from a Weimar perspective", was also conceived as a highly normative enterprise emphasising classical political theory, the institutions and processes of representative government, and the problematic ideological and institutional predispositions peculiar to German political history.

Against this background, the paper's third part looks, on the one hand, at the contribution to "New Left" thinking (1961 ff.) by Ralph Miliband, who studied under Laski and taught at LSE until 1972, and at Paul Hirst's 1990s theory of associative democracy, which builds on Laski's pluralism. On the other hand, the paper considers Karl Dietrich Bracher's seminal work The Failure of the Weimar Republic (1955) and Ernst Fraenkel's 1964 collection Germany and the Western Democracies, which originated, respectively, from the (Research) Institute for Political Science - added to Berlin's Free University in 1950 - and DHfP, re-launched in the same year.

In a brief concluding fourth part, the paper touches on the reception, both in Great Britain and West Germany, of the approaches of "modern" American political science since the mid-1960s.
\end{abstract}

Keywords: associationalism, conservative revolution, democratisation, Fabian Society, pluralism, Weimar Republic

\section{I}

The Fabian Society was set up as an intellectual circle in 1884 by, among others, the two Webbs, George Bernard Shaw, and Graham Wallas. Inspiration for its name came from Fabius Maximus Cunctator, the cautious Roman warlord of the Second Punic War. The 
Fabians' avowed principles were "permeation", "gradualism", and "municipal socialism". Permeation meant the attempt "at incalculat(ing) Socialist thought and Socialist projects into the minds not merely of... political Liberals or Radicals, but also of political conservatives" (Webb 1920, XXVI). Gradualism, which stood for constitutional, "respectable" socialism, was added after the formation of the Labour Party, in which the Society took part. Both principles found expression in a veritable stream of tracts, lectures, commission reports, and proposals for specific legislative or administrative measures, particularly ("bottom-up") on the municipal level. The Fabians influenced the British Labour Party to an extraordinary degree. In 1918, Sidney Webb wrote the party's revised programme. After a generation, more than half of the just under 400 Labour MPs elected in 1945 were Fabians (Beveridge 1952, V) - even if it has been cautioned that this "was just one of the things one 'did' as a Labour activist, like being a member of Co-operatives UK" (Grant 2013, personal communication).

Founding the London School of Economics and Political Science was made possible by windfall money: a 20,000-pound bonanza ("the equivalent of nearly 1 mio. pounds a hundred years later": Dahrendorf 1995, 3) bequeathed to the Fabian Society in 1894 by a supporter who, despairing of a severe illness, took his life. The Webbs' and others' motives (among them Bertrand Russell) have been summarised by Ralf Dahrendorf, much later LSE's director, as "the five E's" (Dahrendorf 1995, 29-46): advanced education for practical purposes, following the model provided by the L'École libre des sciences politiques established in Paris two decades earlier; economics offering, once again, practical advice for current affairs; equality through benevolent social reform and determined collective action; efficiency in the application of modern science, aimed at furthering administrative competence and superior expertise; and finally, somewhat surprisingly, empire, the notion that economic imperialism and social reform might serve as a good combination.

In Germany, an extramural Political Studies Institute, free of the rigid constraints of the country's traditional system of higher education, was twice during the 20th century considered the adequate response to the perceived need of politically educating the German people. In 1920 as in 1949, it would be located in Berlin, and would at the outset resemble an adult education establishment offering evening classes. In 1949, after degeneration into Nazism, it was hoped that political education would "help in providing, with regard to information and comportment, the underpinnings required by a fresh start in democratic politics" (Blanke et al. 1975, 54). Less so in 1920, after Germany had suffered an unexpected defeat in the First World War. According to Theodor Heuss, the first director of studies at DHfP - much later, of course, also the German Federal Republic's first president - German politics, "forced into a system of humiliations by external force and through its own fault, (knew) but one issue: the struggle for national liberation" (Heuss 1921, 33-34).

Ernst Jäckh, DHfP's first and only president, did not mince words either when pronouncing himself in favour of an institute that would provide "a focal point around which to crystallise a new Germany and, thereby, a new Europe imbued with a new spirit (albeit not the pointless, brutal 'spirit' of Versailles)" - referring, of course, to the Versailles Peace Treaty and the constraints it imposed on Germany (Jäckh 1921, 31). After 1945, Jäckh would omit the part about "the pointless, brutal 'spirit' of Versailles" from reprints of his 
earlier speech (Jäckh 1952, 14; id. 1960, 87-88). At the time, however, the revisionist impulse was unmistakable.

The necessary money was initially provided, first and foremost, by the new governments of Germany - usually referred to as the Weimar Republic, named after the city where a constituent assembly had drafted the new constitution - and of the state of Prussia, supplemented by grants from a few liberal industrialists such as Bosch or Siemens. After 1926/27, further financial support came from the Rockefeller Foundation and the Carnegie Endowment for International Peace.

Among the institute's tasks, Jäckh and Heuss included training for the Civil Service and the education of future political "leaders". In addition to the conviction held by large segments of the population and certainly by an overwhelming majority among the Weimar Republic's prominent political and academic players, that the peace treaty concluding the First World War had been unjust and needed to be revised, a second theme ran through the Weimar Republic's political debates: that, in a parliamentary democracy, the selection and training of capable political leaders constituted the major problem. Such over-emphasis on leadership did not least derive from Germany's authoritarian past. During the 1920s, the leadership ideal came to acquire almost "metaphysical significance" in Germany. Before long, it would be tied to "great-man doctrines", favouring an anti-parliamentary and antidemocratic backlash even among self-styled "republicans by force of reason" (Struve 1973, 9; Döring 1975, 231; Faulenbach 1980, 310).

Thus, in the last instance, differences between the two extramural facilities, LSE and DHfP, could hardly have been more marked. Five years after LSE had been set up, a new constitution gave an economics and political science faculty to the University of London, recognising LSE as a university school (Dahrendorf 1995, 32, 56-57). DHfP would have to wait more than half a century for a similar development to occur.

II

No wonder that highly different approaches to political science emerged at LSE and DHfP. A chair of political science was established at the London School in 1914. Until 1950, it was successively held by two reform-minded Fabians, Graham Wallas and Harold Laski, whom informed opinion has included among the half dozen or so "founding fathers" of British political science (Kavanagh 2003, 594).

Wallas viewed the "great society", which had sprung "from steam and electricity", as characterised by impersonal, mechanistic relations (Dewey 1954, 96). Because individuals are affected by "remote, obscure" environments not adequately understood and controlled, they find it difficult to plan their lives. This situation is aggravated by the fact that employment conditions, "often confined to highly repetitious operations", tend to suppress special skills and to narrow perspectives (Heslep 1968, 156). Wallas suggested that employees should work in small groups whose members might interact with each other (ibid., 157), an idea that has remained essential to concepts of industrial democracy. Schooling should be universal, working hours short, women "enfranchised" politically, socially, economically. Some of his other reform proposals sounded rather technocratic. 
Specialised experts should cooperate with legislators, bureaucrats, representatives of the professions and labour unions in "planning" society, including programmes for spacious housing, parks and forest areas, even park benches (ibid., 157-158). Disqualifying such policies as analogous to later fascist "strength through joy" programmes would, however, miss the point. Wallas was essentially a moralist, intent on curbing drunkenness, disorderly conduct, and violence which resulted from tensions and unhappiness.

When Harold Laski was appointed Wallas' successor in 1926, he was on his way to becoming, during the 1930s, "the most important socialist intellectual in the English-speaking world"; already by 1922, a "utopian character" introduced by H. G. Wells in his novel Men Line Gods bore the name Laski (Kramnick and Sheerman 1993, 1-2). He had previously taught at McGill (Montreal) for two, at Harvard for another four years, as an instructor and tutor, and had held a lectureship at LSE for six more years. Borrowing the term "pluralistic" from the philosophy of William James, he had, in a 1915 lecture delivered at Columbia University, introduced it into political theory.

The ideas of the Fabian Society had considerably influenced Laski's thinking. So, for a time, had the argument of the guild socialists - "young rebels" in the Fabians' ranks who held that self-government was identical with representation according to the differentiation of functions on every social level, definitely including the factory and the enterprise. Convinced that "no political democracy (could) be real" without being underpinned "by an economic democracy" (Laski 1919, 38), Laski initially envisioned two participatory machineries - a vocational congress of producers and a territorial parliament of consumers - which would exist side by side, posing major practical problems of coordination.

Laski's 1925 magnum opus, A Grammar of Politics, offered both a textbook on political science and a vision of the "good society". From his previous work, he retained two central contentions:

- "The structure of social organization involves, not myself and the state, my groups and the state, but all these and their interrelationships... The interest of the community is the total result of the whole pressure of social forces" (Laski 1925, 141, 261);

- "Exactly as the evolution of political authority has been concerned with the erection of limitations upon the exercise of power, so also with economic authority... In a sense not less urgent than that in which Lincoln used it, no state can survive that is half-bond and half-free. The citizen... must be given the power to share in the making of those decisions which affect him as a producer if he is... to maximize his freedom" (ibid., 112-113). However, Laski now repudiated the guild socialist project on the grounds that its institutional difficulties would be "insurmountable" (ibid., 72). Instead, he focused on that distinction which has remained pivotal to conceptions of democratising society - the separation of property from control (ibid., 112):

- "Just as the holder of government bonds has no control... over government policy, so it is possible to prevent interference with the direction of an industrial enterprise by the loaners thereto of capital... The present system of private property does not in the least involve the present technique of industrial direction."

In his liberal and socialist commitment both to civil liberties and to "the replacement of economic individualism... by an egalitarian society based on cooperation and public ser- 
vice" (Kramnick \& Sheerman 1993, 3), Laski's "political pluralism used socialism to shape a new interpretation for liberalism" (Griffith 1933, 78). It required the Great Depression of 1929 and the circumstances of the formation of the British National Government in 1932 for Laski to move more clearly in a Marxian direction without, however, as has been erroneously suggested, "rejecting" pluralism (Deane 1955, 153). Rather, by combining pluralism and Marxism, he proposed in 1937 to transcend the capitalist system, envisaging not violent action but, in a term Laski was to coin during the Second World War, a "revolution by consent".

Wallas and particularly Laski typified the emerging discipline of political science in Britain, which was considered "part of a humane tradition, deeply rooted in the classics", wherein prescriptive political theory "maintained a leading role", and whose teachers, as a rule, "were public intellectuals" not "shy(ing) away from political engagement". In addition, LSE and Oxford (Cambridge to a lesser extent) continued to function as inter-war centres for the study of politics (Kelly 2010, VII; Kavanagh 2003, 594, 600, 610; Grant 2010, 12, 14).

The political and social context favoured such a rather unbroken development. The British political tradition and political institutions went largely unchallenged. The Great Reform of 1832 had established the principle of gradual transition to representative democracy, to which the major political parties had increasingly subscribed. Against that backdrop, projects of further democratisation, such as those considered by Laski, might reasonably be envisaged.

In Germany, belated unification had been achieved by Prussian arms under Junker command, rather than by an ascending middle class bent on establishing civil liberty and governmental responsibility. After Imperial Germany's defeat in 1918, not merely detractors of the republic continued to nurse aspirations to recapture the country's pre-war position of power on the continent. In theory as in practice, such revisionism reinforced a functional, instrumentalist approach to both domestic and foreign policy. If democratic government, if the League of Nations proved unable to achieve revision, both might be expendable - which meant that, in German political science, the very principle of democracy was coming under attack.

At DHfP, the functional perception of democracy as merely a (more or less adequate) method of government, and of international conciliation as primarily a tool for achieving revision would, during the final stages of the Weimar Republic, provide an opening for the endorsement of authoritarian "solutions" to Germany's political crisis. On top of that, a growing element among the Berlin Institute's faculty - self-styled "conservative revolutionaries", as they referred to themselves - subscribed to a radicalised, nationalist version of revisionism, unwilling, as they proclaimed, "to let the fatherland perish by the hands of inadequate leaders and external enemies" (Spahn 1925, 3). Increasingly from 1927, DHfP's positions and publications were opened to those intransigent nationalist enemies of the Weimar Republic, whose approach centred on four basic tenets:

A "homogeneous" nation, rooted in "blood and soil", distinct from "atomistic" and "divisive" modern society; a corporatist, supposedly "organic" state, replacing "mechanistic" Western parliamentarism; a belief in authoritarian political leadership, as opposed to democratic "levelling"; finally, the perspective of renewed German hegemony in central 
Europe as a "continuing German mission". This approach amounted to politicised, rather than political science. Inevitably, it paved the way for the Nazi doctrine that no science could escape being political science - in the sense that it had to serve purposes laid down by political, i.e., Nazi, authorities.

The institute split along conceptual lines into nationalist, functionalist, and democratic "schools". In contrast to the functionalists, scholars of democratic persuasion - mostly social democrats according to party affiliation - would teach an approach to domestic and foreign politics focusing on equality and social justice, on peaceful conflict settlement, an abandonment of territorial demands and renunciation of hegemony. They either lost their positions in 1933, or were forced into exile. After 1945, these were the individuals who would come to play a decisive part in the re-establishment of the Berlin Institute.

Differences between the functional and democratic approaches surfaced most visibly in their analyses of Italian fascism and National Socialism. While not mincing words about the "browbeating" of the press and of the opposition parties in Italy, Theodor Heuss maintained that Mussolini's "personality" made him a "leader" (Heuss 1926, 97). When Heuss in 1932 published an inquiry into the German Nazi leader's political development, entitled Hitler's Course, a reviewer was struck by "a lack of flatly repudiating National Socialism's most ruthless attributes" (cf. Jäckel 1968, XXIV). Such lack can hardly be explained by "contemporary uncertainties" (ibid., XXXVI). Rather, it revealed an analytical uncertainty typical of the functional approach. The democratic school, in contrast, predicted that a Nazi regime would bring "the end of the rule of law in a centralized police state" (Neumann 1973 [1 1932 ], 109), even foreseeing that the Nazi party, "forced to let down", after its advent to power, many supporters, would "have to resort to force not just against adversaries, but against a good many followers” (Holborn 1933, 25).

These, however, were rare observations. To pass the acid test, political science at DHfP would have had to focus, first, on the gradual infringement, by established elites, of the Weimar constitution and, second, on the aggressive reactionary populism of the Nazi mass movement. The brief references just quoted indicate the achievements of which a homogeneous discipline, in the sense of a general commitment to democratic values, might have been capable. As matters stood, no adequate analytical assessment of National Socialism emerged at DHfP.

\section{III}

British political scientists of the inter-war period "wrote about themes and issues that still resonate today", and thereby "shaped... the ideas of the post-war makers" of the discipline. There was a continued "reluctance to embrace... theoretical and empirical methodologies." More specifically, Harold Laski's work and intellectual legacy reinforced the tendency toward "a predominance of political theory" - and, at the heart of that theory, debates about the nature of political power and the claims of the state (Kavanagh 2003, 594; Dunleavy, Kelly \& Moran 2000, 4, 6; Kelly 2010, IX-XI, 20).

West German political science, initially pursued "from a Weimar perspective" (Günther $1986,28)$ - which meant a determination to draw lessons from Germany’s recent history - 
was also conceived as a highly normative enterprise. Largely devoid of empirical research and methodological reflection, it emphasised classical political theory, the institutions and decision-making processes of representative democracies, with a special focus on political parties and interest groups, and the distinction of Western political pluralism from "totalitarian rule", both of the Nazi and of the Communist variety.

In 1950, as briefly mentioned before, DHfP was re-launched, again in an attempt to reach out to people outside the normal academic strata. Otto Suhr, who had counted among its pre-1933 instructors and was now serving as social-democratic chair of West Berlin's City Council, became the Institute's first director. Subsequently, he would rise to the position of Lord Mayor. A (Research) Institute for Political Science was added to West Berlin's Free University as a joint DHfP-University enterprise a year later with financial support (Stammer 1960, 175, 177) from the United States. Only by 1959, DHfP itself was integrated into that university as an interdepartmental centre, named after Suhr.

During 1967-1969, the Otto Suhr Institute became a focal point for the movement of radical dissent, in which political science and sociology students played an influential part. LSE, too, was affected - even if less drastically - by "the troubles", as accounts were wont to refer to the explosion of student discontents (Dahrendorf 1995, 443). For a time, and to a certain extent, the sort of partial "rearrangement of research priorities" followed which David Easton had felt bound to demand from the discipline, including the construction of political alternatives, rather than "uncritically acquiesc(ing) in prevailing politics" (Easton 1969, 1058-1059, 1061).

The rest of the paper will very briefly look, on the one hand, at the contribution to British "New Left" thinking by Ralph Miliband, who studied under Laski and taught at LSE until 1972 (after his death, a Ralph Miliband Programme of public lectures and fellowships would be set up at LSE), and at Paul Hirst's 1990s theory of associative democracy, which built on Laski's pluralism. On the other hand, the paper will briefly discuss Karl Dietrich Bracher's seminal work The Disintegration of the Weimar Republic and Ernst Fraenkel's 1964 collection Germany and the Western Democracies, originating, respectively, in 1955 and 1964 from the (Research) Institute of Political Science and the re-launched DHfP.

Ralph Miliband (1924-1994) fled to England from Belgium during the Second World War, served in the British navy and studied at LSE, where Laski became his intellectual mentor. He subsequently taught there as a lecturer, was appointed a professor at Leeds University, and went on to teach in Canada and the US. In 1959, Miliband helped launch the New Left Review and in 1964 the Socialist Register as an annual "survey of movements and ideas" (Miliband 1994). His influential 1961 study, Parliamentary Socialism, offering a critique of the consequences of the Labour Party's approach to politics since 1900, undertook to prove that the Labour Party "had always been 'dogmatic, not about socialism', but about a conventional interpretation of 'the parliamentary system'. This had insulated the leadership from the mass party", had "rendered them both unwilling and unable to educate and mobilise for radical purposes their own class and activist base", and had "regularly turned to the detriment of the working classes and the advantage of Conservatism" (Panitch 1995; Miliband 1972, 13, 348). 
Miliband went on to write The State in Capitalist Society (1969), where he focused on what he termed "hegemonic" processes maintaining bourgeois class rule through value-setting and fragmenting workers' class identity by a multitude of agencies in society, culture and the mass media, education, and, finally, by political party machines. "Careful to acknowledge the positive features in 'bourgeois democracy', such as diversity of opinion and of freedoms", he became increasingly critical not only of the Soviet Union, but also of Cuba and China (Newman 2002, 197, 229). In Marxism and Politics (1977), Miliband argued that if Marxists continued to regard politics "as an epiphenomenon" of economics, it would be impossible to construct that democracy which "he regarded as an integral part of socialism", involving "a vast extension of democratic participation in all areas of civic life" (ibid., 233, 236).

During that same period, questions of liberal democracy and representative government certainly provided the "dominant paradigm" for British political science. As in the German case, fascism and Stalinism had "discredited a variety of alternatives to and critical views of representative democracy". However, during the last decades of the 20th century, the failings of representative government - in particular, "low levels of governmental accountability" and "defective electoral and/or party systems" - became apparent. It has been judged that these decades saw "an increasingly successful challenge" to that paradigm in British political science, part of which was presaged by "notable figures such as Ralph Miliband" and other New Left thinkers (Hirst 1989, 1; Hirst 1994, 3; Kelly 2010, 25).

Projects of “"workers' control' and industrial democracy..., echoing ideas" of the early Laski and of G. D. H. Cole, also helped the concepts of pluralism and associationalism to resurface "as paths to democracy" (Kelly 2010, 27). The principal protagonist of this rediscovery was the radical political theorist Paul Hirst (1947-2003). Editing a volume of Cole's and Laski's writings in 1989, he proclaimed as its purpose to put that "important body of work back on the current agenda of political theory" (Hirst 1989, 1). Five years later, he presented what he termed a "model of associational governance in the economy and the welfare [state] sectors" (Hirst 1994, 43). Hirst carefully emphasised that he was not envisaging some "transition to an associationalist utopia", but was rather offering a "democratiz(ing)...supplement to our failing institutions...: representative mass democracy, bureaucratic state welfare and the big corporation" (ibid., 42-43). From there he proceeded to lay the foundations of associationalist ethics, associationalist management of the economy by locally based, democratically governed firms and decentralised capital-labour bargaining, and finally an associationalist system of public services through the introduction of self-governing voluntary agencies in public-private partnership.

From the outset, Hirst (1989, 2-3) had pointed out that "English political pluralism labours under a difficulty in that it shares the word with a different, influential, and contemporary conceptual scheme... refer(ring) to a body of modern American political theory which defines democracy as a form of stable and institutionalized political competition."

In post-Second World War West Germany, the experience of exile in the US during the Nazi regime by political scientists, in particular by the influential Ernst Fraenkel (18981975), favoured the emergence of a "neo"-pluralist concept largely analogous to the Amer- 
ican model and indeed influenced by it. The approach was judged in retrospect "probably the most important product of the early stage of (West-German) political science" (Blanke et al. 1975, 76).

Expressly repudiating Laski's variety of political pluralism, and substituting totalitarianism - "the construct beyond the 'Iron Curtain' and the Wall" (Fraenkel 1968, 165) - for state monism as the principal counterpart to pluralism, the notion served as a perfect Cold War term. Fraenkel, who pushed it vigorously, did not mince his words in professing that neo-pluralism was "fighting - to say nothing of Hitler's shadow - the much-less faded shadow of Stalin" (ibid., 187).

Hitler's shadow: in 1954, a historical section had been added to Berlin's (Research) Institute of Political Science. It came to be directed by Karl Dietrich Bracher, a 32 year-old scholar whose experience with American democracy - derived, first, from lectures during two years in a US POW camp and, subsequently, from post-doctoral studies at Harvard had fostered his desire to come to grips with the catastrophe of Nazism (Rupp and Noetzel 1994, 18). His 800-page volume The Disintegration of the Weimar Republic was recognised, four years after publication, as "without question the most important study dealing with the Weimar Republic that has appeared to date" (Epstein 1959, 62), and has stood the test of time very well. Combining profound structural analysis with a formidable richness of historical detail, Bracher's book focused on the reasons for and the many strands of the "widespread movement" (ibid.) to replace democracy by dictatorship that emerged after 1919 and rapidly gained momentum during 1930-1933. Bracher explicitly stated his aim to contribute, by his analysis, to the foundations of a democratic polity (Bracher 1978 [1955], XIX).

\section{IV}

Since the 1960s, normative paradigms, both in Great Britain and in West Germany, have been challenged by the onslaught of the behaviouralist and systems theory approaches which "modern" American political science developed. If at LSE, the Department of Politics (now labelled Government Department) continued to attract a "set of outstanding individual scholars", their common denominator would, however, remain "the absence of empirical political science" (Dahrendorf 1995, 415).

In his 1957 LSE doctoral thesis, Bernard Crick (later Sir Bernard Crick, 1929-2008) incisively argued that "the construction of a democratic order... required a historical study of politics rather than the scientism of the behavioralists" (Grant 2010, 35). Published two years later, Crick's American Science of Politics "became a very influential book" (ibid., 34); the work's dictum, "Politics is normally the application of experience to the creative conciliation of differing interests" (Crick 1959, 221) may be considered thoroughly in the spirit of British political studies. Another three years later, in a chapter of his even more renowned volume In Defence of Politics, Crick once again rejected any major role of scientism for the discipline (Crick 1964 ${ }^{\text {2rev }}$ ). Appointed a lecturer at LSE and subsequently Professor of Political Theory at Sheffield University, Crick was knighted in 2002 for "ser- 
vices to citizenship in [secondary] schools", where his efforts had led to the establishment of compulsory citizenship classes.

To some extent, Crick's attitude would seem to mirror the overall response of the British discipline to the "American challenge": acceptance of the overseas model has been "reluctant"; integration of American approaches happened in "homeopathic doses"; and normative political theory has retained a considerably stronger position (Grant 2010, 33, $163,167)$.

In (West) Germany, the discipline's "Americanization", commencing in the mid-1960s, initially progressed more rapidly than in Great Britain. However, the "strengthening of behaviourist approaches was interrupted" by the leftist protest movement of the late 1960s (Beyme 1982, 95). Even then, younger scholars continued to assimilate American methodological concepts, particularly with regard to policy analysis (ibid., 96, 98). Since the 1980s, normative theories have been on the retreat and policy studies on the advance. As a result, German political science impresses the observer as more fragmented today than its British counterpart.

\section{References}

Beveridge, Lord (1952). Introduction. In: Cole M. ed. Beatrice Webb's Diaries. London: Longmans, Green, pp. V-XVIII.

Von Beyme, K. (1982). 'Modern Schools of Politics: Western Germany'. Government \& Opposition. Vol. 17 (1982), pp. 94-107.

Blanke, B., Jürgens, U. and Kastendiek, H. (1975). Kritik der politischen Wissenschaft. Vol. 1. Frankfurt/New York: Campus.

Bracher, K. D. (1978 [ $\left.\left.{ }^{1} 1955\right]\right)$. Die Auflösung der Weimarer Republik. Droste: Düsseldorf/ Königstein: Athenäum.

Crick, B. (1959). The American Science of Politics. Its Origins and Conditions. London: Routledge \& Kegan Paul.

Crick, B. (1964 2rev [11962]). In Defence of Politics. Harmondsworth: Penguin Books.

Dahrendorf, R. (1995). LSE. A History of the London School of Economics and Political Science, 1895-1995. Oxford/New York: Oxford University Press.

Deane, H. A. (1955). The Political Ideas of Harold J. Laski. New York: Columbia University Press.

Dewey, J. (1954). The Public and its Problems. Denver: Alan Swallow.

Döring, H. (1975). Der Weimarer Kreis. Meisenheim: Hain.

Dunleavy, P., Kelly, P. J. and Moran, M. (2000). 'Characterizing the Development of British Political Science’. In: id. eds. British Political Science: 50 Years of Political Studies. Oxford: Blackwell, 3-9.

Easton, D. (1969). 'The New Revolution in Political Science'. American Political Science Review. Vol. LXIII, pp. 1051-1061.

Epstein, K. (1959). '>>Review<< of Karl Dietrich Bracher: Die Auflösung der Weimarer Republik'. Journal of Modern History. Vol. 31, pp. 62-63.

Faulenbach, B. (1980). Ideologie des deutschen Weges. Munich: Beck. 
Fraenkel, E. (1968). Deutschland und die westlichen Demokratien. Stuttgart: Kohlhammer. Grant, W. (2010). The Development of a Discipline. The History of the Political Studies Association. Chichester: Wiley-Blackwell.

Grant, W. (2013). Personal communication.

Griffith, T. H. (1933). Politischer Pluralismus in der zeitgenössischen Philosophie Englands. Dissertation, University of Giessen.

Günther, K. (1986): 'Politikwissenschaft in der Bundesrepublik und die jüngste deutsche Geschichte'. In: von Beyme K. ed. Politikwissenschaft in der Bundesrepublik. PVSSonderheft 17, Op-laden: Westdeutscher Verlag, pp. 27-40.

Heslep, R.D. (1968). 'Graham Wallas and the Great Society'. Educational Theory. Vol. 18, pp. 151-163.

Heuss, T. (1921). 'Denkschrift zur Errichtung einer Deutschen Hochschule für Politik'. In: Politische Bildung. Wille - Wesen - Ziel - Weg. Berlin: Deutsche Verlagsgesellschaft für Politik und Geschichte, pp. 33-37.

Heuss, T. (1926). Staat und Volk. Berlin: Deutsche Buch-Gemeinschaft.

Hirst, P. (1989). 'Introduction'. In: id. ed. The Pluralist Theory of the State. Selected Writings by G. D. H. Cole, J. N. Figgis, and H. J. Laski. London: Routledge, pp. 1-47.

Hirst, P. (1994). Associative Democracy. Cambridge: Polity Press.

Holborn, H. (1933). Weimarer Reichsverfassung und Freiheit der Wissenschaft. Leipzig: Meiner.

Jäckel, E. (1968). 'Einleitung. In: Heuss T. Hitlers Weg, new ed. ['1932]. Tübingen:

Wunderlich, pp. XI-XLIV.

Jäckh, E. (1921). 'Rede'. In: Politische Bildung. Wille - Wesen - Ziel - Weg. Berlin: Deutsche Verlagsgesellschaft für Politik und Geschichte, p. 31.

Jäckh, E. (1952). 'Die >>alte<< Hochschule für Politik'. In: id. Suhr, O. Geschichte der Deutschen Hochschule für Politik. Berlin: Gebr. Weiss, pp. 5-32.

Jäckh, E. (1960). Weltsaat. Stuttgart: Deutsche Verlagsanstalt.

Kavanagh, D. (2003). 'British Political Science in the Inter-War Years: The Emergence of the Founding Fathers'. British Journal of Politics \& International Relations. Vol. 5, 594613.

Kelly, P. (2010). British Political Theory in the Twentieth Century. Chichester: WileyBlackwell.

Kramnick, I. and Sheerman, B. (1993). Harold Laski. A Life on the Left. New York: Penguin. Laski, H. J. (1919). Authority in the Modern State. New Haven: Yale University Press.

Miliband, R. (1972, 1961ํ). Parliamentary Socialism, London: Merlin Press.

Miliband, R. (1994). 'Thirty Years of the Socialist Register' www.marxists.org/archive/ miliband/1994/xx/30socreg.htm.

Laski, H. J. (1925). A Grammar of Politics (reprint 1948). London: George Allen/Unwin.

Neumann, S. (1973, 1932¹). Die Parteien der Weimarer Republik. Stuttgart: Kohlhammer.

Newman, M. (2002). Ralph Miliband and the Politics of the New Left. London: Merlin Press.

Panitch, L. (1995). 'Ralph Miliband, Socialist Intellectual, 1924-1994'. www.marxists.org/ archive/Miliband/biog/panitch.htm. 
Spahn, M. (1922/23). 'Vorspann'. In: Politisches Kolleg, Hochschule für nationale Politik, Vorlesungsverzeichnis 1922/23. Berlin, p. 3.

Struve, W. (1973). Elites Against Democracy. Leadership Ideals in Bourgeois Political Thought in Germany, 1890-1933. Princeton: Princeton University Press.

Webb, S. (1920). 'Introduction'. In: Fabian Essays, ed. Shaw G. B. London: Allen and Unwin, Unwin, pp. XV-XXVII. 